\title{
METODE PENGALIHAN KREDIT SINDIKASI
}

\author{
Arman Nefi ${ }^{1}$ \\ Adiwarman $^{2}$
}

\begin{abstract}
Abstrak
Loan syndication assignment exists in secondary market. Assignment is a legal means to solve liquidity problem or risk management. There are several methods of loan syndication transfer namely, assignment, novation, sub partcipation, subrogation, and cessie. Assignment and participation are the methods of loan syndication transfer originated from common law system. Novation is a method of loan syndication transfer which is known in common law and civil law system as well. Cessie is a method of loan syndication transfer which has a deep root in civil law tradition. All of loan syndication methods are used in secondary loan syndication market. They have different characteristics and legal implications.
\end{abstract}

Kata kunci: metode pengalihan, kredit sindikasi, subrogasi

\section{Pendahuluan}

Pengalihan kredit sindikasi dilakukan di pasar sekunder. Ada beberapa metode pengalihan kredit sindikasi yang lazim dipergunakan yaitu assignment, participation novasi. ${ }^{3}$ Metode lainnya yang juga dipergunakan dalam praktik pengalihan kredit sindikasi adalah melalui cessie ataupun subrogasi. Metode assignment dan participation berasal dari sistem common law, sedangkan cessie berkembang di negara-negara yang menganut sistem hukum Eropa Kontinental, termasuk Indonesia. Subrogasi dan novasi dikenal

${ }^{1}$ Penulis adalah Staf Pengajar untuk Mata Kuliah Hukum di Bidang Pasar Modal, Direktur Pelaksana Lembaga Kajian Pasar Modal Dan Keuangan (LKPMK) Fakultas Hukum Universitas Indonesia.

2 Penulis adalah peneliti pada Lembaga Kajian Pasar Modal dan Keuangan (LKPMK) Fakultas Hukum Universitas Indonesia.

${ }^{3}$ Joseph J. Norton, "International Syndicated Lending and Economic Development in Latin America: The Legal Context", (London: The London Institute of International Banking, Finance \& Development Law in cooperation with The International Financial Law Unit, Centre for Commercial Law Studies, Queen Mary \& Westfield College, University of London, and The SMU Institute of International Banking and Finance, 1997), hal. 56. 
dalam tradisi common law maupun Eropa Kontinental, termasuk Indonesia. Masing-masing metode pengalihan tersebut memiliki karakteristik yang berbeda. Perbedaan karakteristik tersebut membawa konsekuensi dan teknis pelaksanaan yang berbeda pula. Beragam metode pengalihan kredit sindikasi yang ada memberikan pilihan kepada kreditur untuk memilih salah satu yang paling memenuhi kepentingannya.

Metode-metode tersebut dikatakan sebagai metode tradisional dalam pengalihan kredit sindikasi. Dari semua bentuk pengalihan tersebut (equitable) assignment and sub-participation adalah metode yang paling umum dipergunakan. ${ }^{4}$ Karena assignment dapat diselesaikan dengan proses pendokumentasian yang relatif sederhana dan tidak memerlukan perjanjian (seperti dalam transaksi) novasi. ${ }^{5}$ Pemilihan kedua metode tersebut didasarkan pada pertimbangan praktis yang dianggap lebih memfasilitasi kepentingan kreditur sindikasi.

\section{Metode Pengalihan Kredit Sindikasi}

\section{A. Assignment}

Assignment adalah metode pengalihan yang diatur dalam hukum Inggris. Istilah assignment mengandung arti cara atau sarana mengalihkan hak seseorang atau dapat juga mencakup pengalihan hak dan kewajibannya sekaligus berdasarkan perjanjian. ${ }^{6}$ Assignment adalah metode yang membolehkan kreditur mengalihkan hak beserta kewajibannya. Terminologi hukum yang diterapkan dalam assignment sangat penting. ${ }^{7}$ Sumber hukum assignment berasal dari perjanjian kredit sindikasi, The Law of Property Act 1925 (Inggris), dan Pasal 2 dan 9 dari The Uniform Commercial Code. ${ }^{8}$ Assignment merupakan

${ }^{4}$ Norton, Op. Cit., hal. 56.

${ }^{5}$ Brian J. Terry (ed), "Corporate Finance", (Singapore: Toppan Company Pte., Ltd., 1997), hal. 295.

${ }^{6}$ Robert N. Corley and William J. Robert, "Fundamentals of Business Law", (New Jersey: Prentice-Hall Inc., 1974), hal 167.

${ }^{7}$ Corley and Robert, Ibid., hal. 166.

${ }^{8}$ Michael B. Metzger., Jane P. Mallor, A. James Barnes, Thomas Bowers dan Michael J. Phillips, "Business Law And The Regulatory Environment: Concepts and Cases", $7^{\text {th }}$ Edition, Irwin Inc., (Boston: USA, 1989), hal. 308. 
konsep pengalihan yang banyak dipakai dalam perjanjian-perjanjian kredit sindikasi.

Assignment dilakukan dengan cara bank penjual mengalihkan piutang kreditnya kepada bank pembeli dengan menyerahkan hakhaknya terhadap debitur kepada bank pembeli.' Ada dua prinsip penting dalam assignment. In the first place, a debtor is not affected by an assignment of which he has no notice. for this reason it is highly advisable for the assignee to give notice to the debtor, even if the assignment is merely equitable. ${ }^{10}$ Debitur tidak terikat pada assignment yang dilakukan tanpa pemberitahuan kepadanya. Debitur tidak dapat dipersalahkan jika tetap memenuhi kewajiban kepada kreditur (assignor), bukan kepada penerima pengalihan (assignee). Tujuan pemberitahuan adalah untuk kepentingan teknis administratif dan menginformasikan kepada agent bank agar mengalihkan pembayaran kepada kreditur yang baru. In the second place, all assignments are 'subject to equities.' This means that the debtor will be entitled to plead against the assignee any defence which he may have against the assignor." Debitur berhak untuk mempertahankan hak-hak yang diperolehnya dari penjual kredit, jika penerima pengalihan mengabaikan kepentingan debitur dalam pemberian kredit sindikasi yang sebelumnya diterima dari kreditur lama.

Pengalihan (assignment) kredit sindikasi dilaksanakan sebagai suatu pengalihan yang efektif tanpa persetujuan atau kerja sama dari debitur. ${ }^{12}$ Alasan dibolehkannya assignment tanpa harus persetujuan atau diketahui debitur adalah berkaitan dengan masalah reputasi dan alasan komersial. ${ }^{13}$ Bank enggan mendeklarasikan kepada publik melalui media massa mengenai pengalihan piutang kredit sindikasi kepada pihak lain, karena takut hal itu dianggap kelemahan bank atau

9 Ravi C. Tennekoon, "The Law and Regulation of International Finance", (London: Butterworths, 1991), hal. 106. 1989), hal. 378.

${ }^{10}$ P.S. Attiyah. An Introduction to The Contract Law", (London: Clarendon Press,

"Ibid. hal. 736 .

12 Andrew Phang Boon Leong, "Law of Contract". (Singapore: Butterworths, 1994),

13 Ross Cranston, "Principles of Banking Law". $2^{\text {nd }}$ Edition, (London:Oxford University Press. 2002), hal. 361. 
mengurangi kepercayaan debitur. ${ }^{14}$ Bank juga dapat menggunakan ketentuan mengenai prinsip kerahasiaan untuk tidak membuka kepada transaksi pengalihan yang dilakukannya.

Pada prinsipnya pengalihan kredit sindikasi melalui assignment tidak akan mengurangi atau merugikan kepentingan debitur. Debitur berhak memperoleh perlindungan hukum untuk tetap menerima kredit yang telah disepakati dalam perjanjian kredit sindikasi. ${ }^{15}$ Oleh karena itu, debitur tetap dapat menuntut penjual kredit untuk melaksanakan kewajibannya berdasarkan perjanjian kredit sindikasi.

Assignment adalah hasil suatu kesepakatan.

Jika perjanjian kredit sindikasi tidak mencakup soal assignment, maka assignment dapat dilakukan. Sebaliknya, jika dalam perjanjian kredit sindikasi terdapat larangan terhadap assignment atau jika syarat yang harus dipenuhi tidak tercapai, seperti meminta persetujuan debitur terlebih dulu, maka assignment oleh penjual kepada pembeli tidak sah. (Linden Gardens Trust $v$ Linesta Sledge Disposals; St. Martin's Property Corp. v Sir Robert McAlpine \& Sons [1994] 1 A.C. 85 and Hendry $v$ Chartsearch Ltd [1998] CLC 1382). ${ }^{16}$

Walaupun pengalihan tidak diatur dalam perjanjian, kreditur sindikasi dapat melakukannya. Atau sepanjang tidak dimuat larangan dalam perjanjian kredit sindikasi, kreditur sindikasi dapat melakukan pengalihan. Atau pengalihan piutang kredit dapat dilakukan sesuai dengan syarat-syarat yang diatur dalam perjanjian kredit sindikasi.

Sebaliknya, untuk melarang pengalihan piutang kredit sindikasi, para pihak harus menyatakannya dalam perjanjian kredit sindikasi. Efektivitas pelarangan dilakukannya assignment dalam perjanjian kredit sindikasi diakui oleh pengadilan. Kasus Tom Shaw \& Co vs Moss Empires Ltd (1908) dan kasus Don King Productions Inc. vs Warren [2000] menunjukkan pengakuan pengadilan terhadap klausul

${ }^{14}$ Ibid.

${ }^{15}$ Griffiths O'Melveny Gwendoline. 2004. Common Law Issues in Sales of Loan Portfolios. Makalah disampaikan dalam International Bar Association Financial Service Section Conference-Auckland, New Zealand, 28 Oktober 2004, hal. 2. Diakses dari $<$ www.omm.com>, diakses tanggal 30 September 2005, hal. 10.

${ }^{16}$ Ibid. 
antiassignment. ${ }^{17}$ Perjanjian menjadi rujukan utama para pihak dan pengadilan mengenai pengalihan kredit sindikasi.

Legal assignment berlaku efektif pada saat sejak tanggal pemberitahuan dan syarat-syaratnya terpenuhi. Sepanjang masih ada hal-hal yang tidak terpenuhi dari syarat-syarat yang ditentukan oleh Pasal 136 Law of Property Act 1925, dianggap tidak terjadi pengalihan kredit sindikasi melalui legal assignment. Kegagalan atau keengganan kreditur sindikasi untuk memenuhi persyaratan legal assignment tidak menjadikan pengalihan kredit sindikasi batal, tetapi pengalihan tersebut tidak dapat dikatakan sebagai legal assignment. Sekalipun assignment tersebut dinyatakan batal sebagai legal assignment, tetapi pengalihan kredit sindikasi dinyatakan telah terjadi dengan dianggap sebagai equitable assignment yang sempurna. ${ }^{18}$ Secara hukum, pengalihan kredit sindikasi telah terjadi. equitable assignment yang termasuk dalam kewenangan equity. ${ }^{19}$

Melalui equitable assignement, kreditur sindikasi memiliki koridor yang lebih memungkinkan untuk mengalihkan kredit sindikasinya secara leluasa. Equitable assignment banyak dilakukan dalam kredit sindikasi. Equitable assignment bersifat fleksibel dan lebih menarik bagi kreditur sindikasi, karena memberikan pilihan untuk mengalihkan seluruh piutang atau sebagian. Konsep pengalihan melalui metode equitable assignment ini juga diadopsi dalam perjanjian-perjanjian kredit sindikasi di Indonesia.

Terdapat beberapa hal penting pada equitable assignment. Pertama, kreditur berhak kapan saja untuk melakukan pengalihan kredit kepada bank lain atau institusi keuangan lainnya. Kedua, kreditur dapat melakukan untuk seluruh atau sebagian dari hak dan

${ }^{17}$ Ibid., hal. 11.

${ }^{18}$ Boon Leong, Op. Cit., hal. 729.

19 Equity adalah sistem yang terdiri dari doktrin dan prosedur hukum yang berkembang berdampingan dengan common law dan statute law yang berlaku di Inggris. Sjahdeini. Sutan Remy, 1997. Kredit Sindikasi: Proses Pembentukan dan Aspek Hukum. Jakarta: Pustaka Utama Grafiti., hal. 85. <www.wikipedia.com> diakses pada tanggal 3 Oktober 2005. Equity is the name given to the whole area of the legal system in countries following the English common law tradition that resolves disputes between persons by resort to principles of fairness and justness. Equity comes into play typically when none of the parties to the dispute has done anything against the law, but their rights or claims are in conflict. Thus, it is to be contrasted with "law," which is the legal principles from the common law, the laws enacted by governments, and the "case law" (the principles set forth in courts' opinions deciding cases). 
kewajiban. Ketiga, kreditur harus menyerahkan akta pengalihan kepada agent. Keempat, pemberitahuan pengalihan kredit sindikasi sah jika dilakukan secara tertulis dan ditandatangani.

Fleksibilitas equitable assignment mengenai porsi kredit sindikasi yang dapat dialihkan memudahkan bank-bank melakukan pengalihan kredit sindikasi sesuai dengan pertimbangan dan kepentingannya. Bank kreditur sindikasi dapat melakukan pengalihan sebagian porsi kredit sindikasinya kepada pihak lain dan tetap menjadi kreditur dalam kredit sindikasi. Hal ini penting bagi bank, karena keikutsertaan dalam kredit sindikasi memberikan citra yang positif bagi bank, sebagai bank yang kredibel dan bonafide.

Equitable assignment lebih banyak dipakai dalam perjanjian kredit sindikasi semata-mata didasarkan pada alasan praktis.

Assignments used to effect loan asset transfers are often equitable (rather than legal) because no notice is given to the borrower or because the assignment is only of part of the relevant debt (Raiffeisen Zentralbank Oste rreich $A G v$ Five Star General Trading LLC (The Mount 1) [2001] EWCA Civ 68; [2001] 2 W.L.R. 1344 at [60], [75]). ${ }^{20}$

(Assignment yang biasa dipergunakan adalah equitable assignment (ketimbang legal assignment) sebab tiada diperlukan pemberitahuan kepada debitur atau sebab assignment hanya berkaitan dengan utang tertentu)

Secara teknis, lebih mudah dan menguntungkan bank kreditur sindikasi melakukan pengalihan piutang kredit sindikasi melalui equitable assignment. Tanpa adanya pemberitahuan kepada debitur, pengalihan piutang kredit sindikasi tetap sah.

\section{B. Sub-Participation}

Dalam transaksi sub-participation, bank kreditur sindikasi membuat perjanjian (bilateral) dengan bank partisipan mengenai penyediaan sebagian dana dari keseluruhan jumlah komitmen bank kreditur sindikasi dalam kredit sindikasi. Bank partisipan setuju untuk menyediakan sejumlah uang ketika pencairan kredit telah jatuh tempo sesuai dengan butir perjanjian kredit sindikasi.

${ }^{20}$ Gwendoline, Op. Cit., hal. 10-12. 
Sub-participation dilakukan dengan cara bank kreditur sindikasi yang ingin mengalihkan kreditnya membuat perjanjian di bawah tangan. Dalam pengalihan kredit sindikasi melalui sub-participation, bank partisipan mendepositokan sejumlah uang kepada bank kreditur sindikasi setara dengan jumlah partisipasinya dalam kredit sindikasi. ${ }^{21}$ Bank partisipan menyediakan sejumlah uang yang disanggupinya yang merupakan bagian dari keseluruhan komitmen pinjaman kreditur sindikasi. Dana tersebut berada dalam rekening bank kreditur sindikasi dan akan ditransfer ketika agen sindikasi melakukan penarikan. Bank kreditur sindikasi menjalankan komitmennya dalam kredit sindikasi hingga penarikan terakhir dilaksanakan.

Sebagai imbalan (kontraprestasi) untuk kesediaan bank partisipan menempatkan sejumlah uang yang setara dengan bagian tertentu dari komitmen kreditur, kreditur membayar sejumlah uang kepada bank partisipan kreditur yang setara dengan bagian partisipasi bank partisipan. Bank kreditur sindikasi akan membayar angsuran utang pokok dan bunga berdasarkan perjanjian kredit sindikasi, penjual subparticipation akan membayar sejumlah uang kepada bank partisipan setara dengan jumlah partisipasinya. ${ }^{22}$ Hubungan hukum bank kreditur dan bank partisipan bersifat diam-diam dan membutuhkan kepercayaan.

Sub participation sangat fleksibel yang memungkinkan penjual dan pembeli bernegosiasi dan bersepakat mengenai proporsi bunga dan fee yang masih dimiliki penjual berdasarkan perjanjian kredit sindikasi dan proporsi pokok pinjaman dan bunga yang menjadi hak bank partisipan. ${ }^{23}$ Tidak ada batasan berapa besar persentase kredit sindikasi yang dapat dialihkan melalui sub-participation. Bahkan kreditur sindikasi dapat melakukan sub-participation dengan beberapa partisipan.

Secara hukum, dalam transaksi sub-participation tidak ada penjualan piutang kredit. Kreditur sindikasi tetap memiliki hak hukum terhadap aset kredit, sehingga hak dan kewajiban berdasarkan perjanjian kredit dengan debitur tidak terpengaruh dan pembeli piutang kredit tidak memperoleh hak atau kewajiban sebagaimana semestinya terdapat dalam perjanjian. ${ }^{24}$ Bank kreditur sindikasi tetap

\footnotetext{
${ }^{21}$ Tennekoon, Op. Cit., hal. 108.

${ }^{22}$ Gwendoline, Op. Cit., hal. 15.

${ }^{23}$ Ibid.
} 
melaksanakan kewajibannya menyediakan dana pinjaman yang telah disanggupinya dalam perjanjian kredit sindikasi.

Dalam transaksi sub-participation, kedudukan hukum bank partisipan lemah, karena tidak memiliki perlindungan hukum (unsecured creditor) dalam hal kreditur sindikasi insolvent akibat dilikuidasi atau dipailitkan. Bank partisipan tidak memiliki hak klaim langsung terhadap debitur, karena bank partisipan bukan penerima pengalihan (assignee). ${ }^{25}$ Sub-participation tidak juga mengubah kedudukan partisipan menjadi kreditur peserta sindikasi. Karena bank partisipan adalah kreditur dari kreditur sindikasi bukan kreditur dari debitur. ${ }^{26}$ Partisipan hanya memiliki hubungan hukum dengan bank kreditur sindikasi. Konsekuensinya, jika debitur wanprestasi dan menyebabkan kreditur menjadi insolvent, bank partisipan tidak memiliki hak untuk menuntut kepada kreditur mayoritas. ${ }^{27}$ Bank partisipan merupakan kreditur yang lemah dalam hal wanprestasi debitur yang menyebabkan kreditur menjadi tidak mampu melaksanakan kewajibannya terhadap bank partisipan. Kemungkinan kedua adalah bank partisipan tidak memiliki kewenangan untuk mengajukan tuntutan hukum ketika kreditur sindikasi kehilangan kapasitas hukum karena dilikuidasi atau dinyatakan pailit.

Untuk mengatasi hal itu, atau setidaknya meminimalisasi risiko kerugian bank partisipan, transaksi sub-participation dibuat dengan memberikan hak kepada bank partisipan atas benda jaminan kredit (collateral). ${ }^{28}$ Dalam hal bank kreditur, insolvent bank partisipan hanya berhak atas harta (boedel) pailit bank kreditur sindikasi untuk memperoleh haknya dari partisipasi yang dilaksanakannya untuk kreditur sindikasi. Bank partisipan memperoleh perlindungan hukum dengan adanya hak terhadap benda jaminan yang diberikan bank kreditur sindikasi yang diperjanjikan dalam perjanjikan subparticipation.

\footnotetext{
${ }^{24}$ Gwendoline, Ibid., hal. 15

${ }^{25}$ Norton, Op. Cit., hal. 24.

${ }^{26}$ Ibid.

${ }^{27}$ Ibid.

${ }^{28}$ Ibid.
} 


\section{Novasi}

Konsep novasi berasal civil law, tetapi negara-negara yang menganut sistem hukum common law juga mengenal metode pengalihan kredit sindikasi melalui novasi. Novasi adalah metode tradisional yang dapat dipakai untuk melakukan pengalihan kredit sindikasi. ${ }^{29}$ Novasi adalah metode pengalihan kredit sindikasi dengan cara melakukan pergantian kreditur dengan persetujuan semua pihak yang terikat dengan perjanjian kredit sindikasi. Pergantian kreditur sindikasi dilakukan dengan jalan membatalkan perjanjian kredit yang lama dan membuat perjanjian kredit sindikasi baru.

Prinsip utama dalam novasi adalah menghapus perjanjian kredit sindikasi dengan membuat perjanjian kredit sindikasi yang baru. Kemungkinan perjanjian kredit sindikasi yang baru memuat sejumlah hal yang sama sekali berbeda dengan substansi perjanjian kredit sindikasi yang lama. Sifat dari perjanjian novasi adalah membebaskan kreditur lama dari hak dan kewajibannya (liberatoir), karena telah digantikan oleh kreditur baru. Karena sifat novasi adalah pembaruan utang maka, pembuatan perjanjian novasi memerlukan persetujuan dari pihak-pihak kreditur/debitur lama, kreditur/debitur baru.

Secara sederhana, novasi dikatakan sebagai penunjukkan pihak lain untuk melaksanakan kewajiban. Penunjukkan orang lain untuk melaksanakan tugas sesuai dengan perjanjian disebut dengan pendelegasian. $^{30}$ Novasi diidentikkan dengan pendelegasian. Pendelegasian tugas terjadi ketika obligor mengindikasikan keinginan untuk menunjuk pihak atau orang lain untuk melaksanakan kewajibannya sesuai dengan perjanjian." Tidak hanya kreditur yang dapat menunjuk pihak lain untuk menggantikan kedudukannya, tetapi juga dimungkinkan penunjukkan dilakukan oleh debitur. Pihak penunjuk pendelegasian tetap bertanggung jawab kepada penerima pendelegasian, kecuali penerima pendelegasian setuju untuk menggantikan janji pihak kreditur. ${ }^{32}$ Sepanjang diperjanjikan, penerima pengalihan atau pendelegasian dapat mengambil alih seluruh komitmen kreditur. Oleh karena itu, novasi terjadi ketika obligee

\footnotetext{
${ }^{29}$ Tennekoon. Op ('it. hal. 107.

${ }^{30}$ Metzger et al Op (it. hal. 307

"Ibid hal. 313

${ }^{32} \mathrm{lbld}$
} 
setuju untuk melepaskan pihak penerima delegasi dalam menggantikan pemberi pendelegasian yang berjanji untuk melaksanakan janjinya. ${ }^{33}$ Persetujuan debitur sangat penting dalam transaksi novasi. Signifikansi dari novasi yang efektif adalah pelaksanaan oleh penerima delegasi akan menghapus pihak yang memberi delegasi. ${ }^{34}$ Novasi adalah perbuatan hukum yang bersifat menghapus kedudukan hukum kreditur atau perjanjian untuk menjaga keterlaksanaan pemberian kredit sindikasi.

Syarat umum yang harus dipenuhi agar suatu novasi sesuai dengan ketentuan adalah sebagai berikut: ${ }^{35}$

1. Novasi tidak boleh melanggar perjanjian (the underlying agreement). Kalau perjanjian kredit sindikasi menyatakan tidak dapat dilakukan pembaruan utang, maka novasi yang dilakukan dapat dinyatakan batal demi hukum.

2. Untuk melakukan novasi, diperlukan persetujuan dari semua pihak yang dalam kredit sindikasi yaitu para kreditur sindikasi dan debitur.

3. Pihak yang melepaskan hak dan kewajibannya melalui novasi tidak perlu mempertahankan kepentingan yang tersisa (residual interest) dalam kredit sindikasi. Begitu novasi rampung dilaksanakan maka segala hak dan kewajiban beralih. Kreditur sindikasi yang telah melakukan novasi tidak dapat menuntut hakhaknya yang tersisa, karena ia sudah bukan pihak dalam kredit sindikasi.

4. Pihak yang menggantikan kedudukan kreditur sindikasi melalui novasi tidak dapat menuntut penggantian kepada kreditur lama untuk segala kerugian. Mantan kreditur telah dilepaskan secara hukum dari segala hak dan kewajiban yang terdapat dalam kredit sindikasi.

5. Tidak perlu ada kewajiban membeli kembali bagian (kredit) oleh penjual. Sekali novasi sempurna dilaksanakan, maka mantan kreditur sindikasi tidak memiliki hak atau kemungkinan untuk

${ }^{33}$ Metzger et.al., Ibid., hal. 313.

${ }^{34}$ Ibid.

${ }^{35}$ Agasha Mugasha, "The Secondary Market for Syndicated Loans: Loans Trading, Credit Derivatives, and Collateral Debt Obligation". Banking \& Finance Law Review February, 2004. Canada: CARSWELL, a Division of Thomson Canada Ltd., 2004, hal. 6. . 
membeli kembali (buy back) bagian kredit yang telah dialihkannya.

6. Konsekuensi dari kedudukan sebagai pengganti kreditur lama, segala negosiasi kembali menjadi tanggungan kreditur baru. Setelah novasi, pembeli menjadi pihak dalam kredit sindikasi. Segala hal yang perlu untuk diubah atau dinegosiasikan dalam kredit sindikasi adalah tanggung jawabnya.

7. Mantan kreditur sindikasi juga memasukkan biaya-biaya dan fee yang belum diterimanya, maka kreditur baru harus memasukkannya dalam pembayaran. Sesuai dengan prinsip novasi, bahwa sekali novasi rampung dilaksanakan, maka semua hak dan kewajiban beralih kepada kreditur baru. Kreditur lama dilepaskan secara hukum dari hak dan kewajibannya. Jika penjual novasi belum menerima pembayaran atas biaya-biaya atau fee yang menjadi haknya ketika novasi belum dilaksanakan, sementara penjualan kredit sindikasi mencakup biaya-biaya dan fee tersebut, maka kreditur sindikasi baru membayarkan terlebih dulu termasuk dalam pembayaran untuk kepada kreditur lama.

Novasi dapat secara efektif mengalihkan kewajiban, suatu hal yang tidak dapat dilakukan dalam (legal) assignment. ${ }^{36}$ Implikasi hukum dari novasi adalah terjadi peralihan hak dan kewajiban dari kreditur kepada bank partisipan. Bank partisipan menggantikan kreditur sindikasi yang mana hak dan kewajibannya sesuai dengan bagian partisipasi bank partisipan dan kreditur melepaskan sejumlah tertentu yang menjadi bagian dari kewajibannya. ${ }^{37}$ Pihak yang menggantikan kreditur sindikasi tidak hanya menerima pengalihan hak, tetapi juga kewajiban untuk menyediakan dana pinjaman yang telah disanggupi kreditur sindikasi dalam perjanjian kredit sindikasi.

Bank peserta sindikasi tidak lagi berkewajiban menyediakan kredit karena telah digantikan oleh bank partisipan. ${ }^{38}$ Semua kewajiban beserta prosedur dan tata cara yang berkaitan dengan pemberian kredit dilaksanakan oleh bank partisipan yang telah menggantikan posisi kreditur lama sebagai kreditur. Demikian pula sebaliknya, semua hak beserta prosedur dan tata cara yang berkaitan dengan pemenuhan kewajiban debitur akan dinikmati oleh bank partisipan.Bank partisipan

\footnotetext{
${ }^{36}$ Cranston, Op. Cit., hal. 356.

${ }^{37}$ Norton, Op. Cit., hal. 56.

${ }^{38}$ Ibid., hal. 56.
} 
menjadi kreditur dalam kredit sindikasi berhak atas pembayaran angsuran pokok beserta bunganya dan menanggung kewajiban menyediakan dana kredit. Pergantian kreditur tersebut sudah selayaknya diketahui oleh debitur, mengingat pemberian kredit sindikasi merupakan persetujuan yang berjangka waktu, memerlukan administrasi dan dilakukan dengan prosedur serta tata cara yang telah disepakati.

Novasi melibatkan debitur dan pihak-pihak lain dalam perjanjian kredit sindikasi (original loan syndication agreement) seperti bank kreditur dan agen sindikasi (agent bank). ${ }^{39}$ Novasi adalah metode pengalihan piutang yang melibatkan semua pihak dalam kredit sindikasi yaitu agent bank, bank-bank kreditur lain, bank partisipan (pembeli) dan debitur. In novations, the lead lender, the participating bank, and the borrower agree or consent to novate a portion of the loan agreement to the participating bank. ${ }^{40}$ (Dalam novasi, kreditur utama (mayoritas), bank kreditur sindikasi dan debitur sepakat atau setuju untuk mengalihkan porsi dari perjanjian kredit kepada bank pengganti). Dapat dipastikan novasi tidak dapat dilakukan secara diam-diam, karena novasi membutuhkan persetujuan debitur dan kreditur-kreditur sindikasi lain serta diketahui agent bank.

Pengalihan kredit sindikasi dengan menggunakan novasi jauh lebih rumit, karena menyangkut hak dan kewajiban serta berkaitan dengan hubungan antarkreditur sindikasi. Hal ini dikarenakan hubungan antarkreditur sindikasi didasarkan pada prinsip kerja sama dan kebersamaan. ${ }^{41}$ Agen sindikasi akan menarik sejumlah dana kredit dari setiap kreditur secara proposional sesuai dengan besar komitmennya. Demikian pula dalam pengembalian kredit dan pembayaran bunga, agen sindikasi akan menagih pembayaran dari debitur dan mendistribusikan pengembalian kredit dan pembayaran bunga serta fee secara proporsional pula berdasarkan besar kreditnya. Oleh karena itu, pengalihan piutang kredit sindikasi dengan cara novasi mengharuskan adanya persetujuan dari seluruh kreditur sindikasi. Keharusan ini melahirkan kesulitan bagi pihak yang hendak

${ }^{39}$ Gwendoline, Op. Cit., hal. 7.

${ }^{40}$ Norton. Op. Cit., hal. 56.

41 Andrey U. Sitanggang, "Asas Persetujuan Kreditur Mayoritas dalam Penyelesaian Kredit Macet Sindikasi: Suatu Kajian Dalam Rangka Pengembangan Perbankan Indonesia", Disertasi. Bandung:Universitas Padjajaran, 2007. 
melakukan novasi. Karena itu, dalam praktik, novasi jarang dipilih dan dipergunakan sebagai metode pengalihan kredit. ${ }^{42}$ Sekalipun jarang dipergunakan dalam pengalihan kredit sindikasi, novasi menjadi dasar untuk memodifikasi metode-metode yang berkembang kemudian.

\section{Novasi Objektif}

Apabila seorang berutang membuat suatu perikatan utang baru guna orang yang mengutangkan kepadanya, yang menggantikan utang yang lama yang dihapuskan karenanya. Pergantian perikatan lama dengan perikatan baru (novasi objektif). ${ }^{43}$ Yang dimaksud dengan novasi objektif adalah suatu novasi di mana perikatan yang lama diganti dengan perikatan yang baru, yang di dalamnya mengandung suatu objek perikatan yang lain. ${ }^{44}$ Pengalihan kredit sindikasi melalui novasi objektif dilakukan dengan mengganti perjanjian yang lama dengan perjanjian kredit sindikasi yang baru. Penggantian perjanjian ini dapat berupa perubahan substansi-substansi tertentu atau mengganti seluruh perjanjian.

\section{Novasi Subjektif}

Novasi subjektif adalah pengalihan kredit sindikasi dengan jalan mengganti kreditur atau debitur. Novasi subjektif terbagi dalam dua macam yaitu novasi subjektif pasif dan novasi subjektif aktif. Penggantian debitur lama oleh orang lain yang dikatakan sebagai novasi subjektif pasif. ${ }^{45}$ Dalam kredit sindikasi, pengalihan melalui pergantian debitur boleh dikatakan sangat jarang dilakukan atau sangat kecil kemungkinannya. Bahkan ada larangan untuk melakukan novasi subjektif pasif dalam perjanjian kredit sindikasi, seperti yang dinyatakan dalam perjanjian kredit sindikasi PT. HSBC dan PT. FII, "The Borrower may not assign or transfer any rights and obligation under the Finance

${ }^{42}$ Tennekoon. Op. Cit., hal. 107.

43 J. Satrio, "Cessie, Subrogatie, Novatie, Kompensasi \& Percampuran Hutang", (Bandung: Alumni, 1999), hal. 103.

${ }^{44}$ Ibid., hal. 106.

${ }^{45}$ Ibid., hal. 103. 
Document." Penggantian debitur dalam kredit sindikasi adalah apabila seorang/pihak berutang baru ditunjuk oleh para kreditur sindikasi untuk menggantikan debitur lama, oleh yang berpiutang (kreditur sindikasi) dibebaskan dari perikatannya. Secara teoritis, novasi subjektif pasif dapat dilakukan, namun untuk kondisi yang sangat mendesak dan merupakan pilihan satu-satunya.

Novasi subjektif pasif juga memerlukan prosedur yang tidak sederhana seperti mendapat persetujuan dari para kreditur, setelah sebelumnya para kreditur melakukan tes kepatutan dan kelayakan calon pengganti debitur untuk meneruskan proyek debitur lama. Prinsip utama dalam novasi subjektif pasif adalah menyelamatkan kredit sindikasi dari ancaman macet. Kredit macet adalah ancaman bagi kelangsungan hidup suatu bank. Oleh karena itu, memilih mengganti debitur, menurut hemat penulis tetap memberikan peluang untuk menyelamatkan kredit sindikasi dari ancaman macet.

Berbeda dengan novasi subjektif pasif, penggantian kreditur sindikasi atau novasi subjektif aktif lebih memungkinkan untuk dilakukan. Pengalihan kredit sindikasi dari bank kreditur kepada bank lain di mana kreditur baru ditunjuk menggantikan kreditur lama dikatakan sebagai peristiwa yang diistilahkan dengan novasi subjektif aktif. ${ }^{46}$ Novasi subjektif aktif adalah apabila, sebagai akibat suatu perjanjian baru, kreditur sindikasi baru ditunjuk untuk menggantikan kreditur sindikasi lama, terhadap siapa debitur dibebaskan dari perikatannya dan memiliki hubungan utang dengan kreditur sindikasi baru.

\section{Cessie}

Metode lain yang dapat dipergunakan dalam praktik pengalihan kredit sindikasi di Indonesia adalah melalui cessie. Dalam beberapa hal cessie memiliki kesamaan dengan assignment dalam terminologi pengalihan menurut common law. Secara prinsip, cessie, menurut ketentuan KUH Perdata pasal 613 adalah penyerahan (pengalihan) piutang. Hal didasarkan pada praktik perdagangan di masyarakat mempergunakan tagihan-tagihan yang umum dikenal yaitu wesel, cek, konosemen dan lain-lain. Selain piutang-piutang yang dikenal masyarakat, piutang tagihan atau dalam bentuk yang kira-kira sama dan bernilai ekonomis, dapat dialihkan. Sebagai hak yang bernilai

${ }^{46}$ Ibid., hal. 103. 
ekonomis adalah sangat memungkinkan bagi pemiliknya untuk menjual tagihannya kepada pihak lain di saat membutuhkan uang, sementara, tagihan tersebut belum jatuh tempo.

Secara hukum, pengalihan piutang atau cessie tersebut tidak menyebabkan hapusnya utang piutang, tetapi hanya menyebabkan pergantian kreditur sebagai konsekuensi terjadinya pengalihan. Cessie diatur dalam Pasal 613 Buku II KUH Perdata. Pasal tersebut yang mengatur "Penyerahan akan piutang-piutang atas nama dan kebendaan tak bertubuh lainnya dilakukan dengan jalan membuat sebuah akta otentik atau di bawah tangan, dengan mana hak-hak atas kebendaan itu dilimpahkan kepada orang lain".

Cessie adalah suatu perbuatan hukum yang pengalihan piutang atas nama yang didasarkan pada peristiwa perdata. ${ }^{47}$ Peristiwa perdata (underlying transaction) dalam pengalihan piutang atas nama adalah jual beli. Menurut Pasal 1457 KUH Perdata jual beli adalah suatu perjanjian, dengan mana pihak yang satu mengikatkan dirinya untuk menyerahkan suatu kebendaan, dan pihak yang lain untuk membayar harga yang telah dijanjikan. Perjanjian jual beli piutang kredit sindikasi bersifat konsensual obligatoir. Artinya baru meletakkan hak dan kewajiban bagi penjual dan pembeli, namun belum mengalihkan kepemilikan. ${ }^{48} \mathrm{Jual}$ beli telah sempurna setelah dilakukan penyerahan hak milik atas piutang kredit.Penyerahan dibedakan dalam dua macam yaitu penyerahan yuridis ${ }^{49}$ dan penyerahan nyata (juridisch levering). ${ }^{50}$ Untuk penyerahan piutang kredit sindikasi diperlukan akta, baik berupa akta otentik maupun akta bawah tangan.

${ }^{47}$ Suharnoko dan Endah Hartati, "Doktrin Subrogasi, Novasi Cessie Dalam Kitab Undang-Undang Hukum Perdata, Niew Nederlands Burgerlijk Wetboek, Code Civil Perancis dan Common Law", (Jakarta: Badan Penerbit Fakultas Hukum Universitas Indonesia dan Prenada Media, 2005), hal. 101.

${ }^{48}$ Ibid., hal. 103.

${ }^{49}$ Penyerahan yuridis adalah menunjuk kepada perbuatan seseorang mengoperkan haknya kepada dan diterima oleh orang lain. Dalam penyerahan ini, pemilik hak menyerahkan bukti kepemilikan atas benda kepada pihak lain, dengan begitu, yang bersangkutan secara hukum dianggap sebagai pemilik benda. Misalnya dalam jual beli tanah, pemilik tanah menyerahkan bukti kepemilikan atas tanah kepada pembeli sebagai kontra prestasi dari pembayaran yang dilakukan pembeli.

${ }^{50}$ Penyerahan nyata adalah penyerahan atas penguasaan nyata atas suatu benda. Dalam penyerahan ini, pemilik hak menyerahkan benda secara langsung kepada pihak lain. Satrio, Ibid., hal. 11. 
J. Satrio menyebutkan adanya syarat umum dan syarat khusus untuk melakukan cessie. Syarat umum melakukan cessie adalah:

1. Hak tagihan sah;

Keabsahan hak tagihan digantungkan pada kausa yang halal. Bahwa piutang tersebut adalah piutang kredit yang menjadi hak pemilikinya (bank kreditur sindikasi);

2. Kreditur memiliki kewenangan untuk melakukan cessie.

Syarat ini dimaksudkan untuk menegaskan atau menjamin bahwa pihak yang melakukan penyerahan adalah pihak yang memiliki kewenangan untuk itu. Bank kreditur sindikasi, berdasarkan perjanjian kredit sindikasi, berhak melakukan cessie atas piutangnya.

Syarat umum ini berkaitan dengan keabsahan, terhadap hak (piutang kredit) dan kewenangan yang dimiliki kreditur. Tidak terpenuhi syarat umum ini, cessie dapat dikatakan batal demi hukum.

Syarat khusus adalah syarat berkaitan dengan prosedur untuk melakukan cessie, yaitu:

1. Berdasarkan Pasal 613 KUH Perdata cessie dilakukan dengan akta baik akta otentik ataupun di bawah tangan. Syarat kesempurnaan cessie adalah ditanda tanganinya akta cessie. Penanda tanganan akta cessie ini menandai terjadinya peralihan piutang kredit sindikasi dari kreditur lama (cedent) kepada kreditur baru (cessionaris). Kreditur baru memiliki hak tagih kepada debitur;

2. Adanya pemberitahuan kepada debitur. Jika cessie dilakukan dalam kredit sindikasi, maka pemberitahuan disampaikan kepada agen sindikasi. Maksud dari syarat ini adalah agar agen sindikasi tidak melakukan pembayaran kepada kreditur lama (cedent), tetapi pembayaran ditujukan kepada kreditur baru (cessionaris). Dengan pemberitahuan ini, kreditur lama (cedent) tidak akan menerima dan dapat menuntut hak yang dulu dinikmatinya setelah dilakukannya pengalihan piutang kredit.

Pengalihan kredit sindikasi melalui cessie adalah pengalihan kredit sindikasi yang sudah ditarik (tagihan/piutang). Pengalihan kredit sindikasi melalui cessie berbeda dengan pengalihan kredit sindikasi yang dilakukan melalui equitable assignment, tidak dapat dilakukan untuk fasilitas kredit sindikasi (komitmen). Pengalihan (piutang) kredit sindikasi melalui cessie tidak serta merta menghapus hak tagih pihak kreditur sampai dipenuhinya syarat-syarat cessie sesuai dengan 
ketentuan Pasal 613 KUH Perdata, yaitu ditandatanganinya akta cessie dan disampaikan pemberitahuan tertulis kepada agen sindikasi. Cessie merupakan salah satu metode pengalihan yang lazim dipakai oleh kreditur sindikasi.

\section{E. Subrogasi}

Subrogasi adalah salah satu metode pengalihan tradisional yang dapat dipakai dalam kredit sindikasi. Pengertian subrogasi terdapat dalam Pasal 1400 KUH Perdata, "subrogasi atau penggantian hak-hak si berpiutang oleh seorang pihak ketiga, yang membayar kepada si berpiutang itu, terjadi baik dengan persetujuan maupun demi undangundang." Subrograsi adalah tampilnya pihak ketiga sebagai kreditur dengan jalan membayar kepada kreditur lama sejumlah uang yang setara dengan utang debitur. Pihak ketiga ini bertindak sebagai pengganti kreditur yang memiliki hak untuk menuntut prestasi debitur.

Subrogasi diatur dalam Pasal 1400 sampai 1403 KUH Perdata. Pasal 1400 KUH Perdata menyatakan subrogasi terjadi karena perjanjian atau undang-undang. Karena pengalihan kredit sindikasi didasarkan pada perjanjian, maka hanya subrogasi yang berdasarkan perjanjian yang relevan untuk pengalihan kredit sindikasi. Menurut pasal 1401 (1) KUH Perdata, subrogasi karena perjanjian menyatakan bahwa kreditur menetapkan pihak ketiga sebagai pihak yang menggantikannya baik untuk segala hak maupun untuk melakukan penuntutan. Pergantian ini dinyatakan dengan tegas dalam perjanjian dan bersamaan dengan pembayaran oleh ketiga kepada kreditur. Dari keterangan tersebut, terdapat beberapa hal yang merupakan syarat terjadinya subrogasi yaitu adanya perjanjian dan pembayaran sebagai dasar pergantian kreditur. Transaksi subrogasi ini melibatkan kreditur dengan pihak ketiga.

Lebih lanjut, ketentuan Pasal 1401 (2) tegas menyatakan bahwa subrogasi ini harus dibuatkan akta otentik, menyebutkan bahwa uang pinjaman tersebut untuk melunasi utang. Sutan Remy Sjahdeini menegaskan bahwa akta tersebut harus menyatakan bahwa pembayaran uang adalah untuk melunasi utang debitur kepada kreditur pertama. ${ }^{51}$ Pembayaran utang berasal dari uang yang dipinjam dari pihak ketiga. Hal ini dimaksudkan untuk memberikan perlindungan kepada pihak ketiga, bila mana ia tidak memperoleh pengembalian

${ }^{51}$ Sjahdeini (2), Op. Cit., hal. 93. 
utangnya di kemudian hari. Dengan begitu pihak ketiga memiliki kedudukan hukum untuk menuntut.

Subrogasi adalah perbuatan hukum yang selalu berkaitan dengan pembayaran utang uang. ${ }^{52}$ Subrogasi terjadi sejauh pihak ketiga membayar piutang kreditur. Hukum tidak mensyaratkan mengenai jumlah pembayaran apakah sepertiga dari utang, setengah atau seluruhnya. Semuanya itu dapat disepakati oleh para pihak. Tentunya jumlah pembayaran akan menentukan hak yang diperoleh pihak ketiga. Asser menegaskan bahwa apabila pihak ketiga membayar sebagian dari piutang, maka hanya untuk bagian itu saja, ia memasuki hak-hak si berpiutang. ${ }^{53}$ Dengan begitu, jika pihak ketiga telah membayar sepertiga bagian piutang kreditur, maka kreditur masih tetap memiliki hak atas utang yang disesuaikan dengan sisa piutangnya. Subrogasi tidak dapat dipergunakan untuk melakukan pengalihan yang menyertakan pelaksanaan komitmen kredit.

Subrogasi dalam sistem common law dibedakan atas simple subrogation dan reviving subrogation. Simple subrogation operates to transfer existing rights of action from one party to another.$^{54}$ Simple subrogation berkaitan dengan hak untuk menuntut pembayaran. Dalam simple subrogation pembayaran yang dilakukan oleh pihak ketiga kepada kreditur oleh hukum dianggap tidak menghapuskan kewajiban debitur kepada kreditur. Karena itu pihak ketiga yang telah membayar utang debitur kepada kreditur tidak dapat langsung menuntut pembayaran kembali dari debitur. ${ }^{55}$ Kegagalan pihak ketiga untuk memperoleh pembayaran dari debitur didasarkan pada transaksi subrogasi yang dilakukan secara diam-diam. Kemungkinan lainnya adalah subrogasi dilakukan untuk sebagian hak saja, sehingga kreditur tetap berhak menagih kepada debitur.

Pada dasarnya, simple subrogation adalah untuk menghindari pemenuhan kewajiban ganda (double payment) oleh kreditur lama setelah pihak ketiga memenuhi kewajiban debitur. Pembayaran ganda yang diperoleh kreditur lama akan menyebabkan terjadinya

52 C. Asser, "Pengajian Hukum Perdata Belanda", diterjemahkan oleh Sulaiman Binol, (Jakarta: Dian Rakyat, 1991), hal. 505.

${ }^{53}$ Ibid., hal. 511.

54 Alastair Hudson, "Equity and Trust", $3^{\text {rd }}$ Edition, (Cavendish Publishing Ltd. 2003), hal. 910.

55 Suharnoko dan Hartati, Op. Cit., hal.2-3. 
pertambahan kekayaan secara tidak adil atau unjust enrichment dan pihak ketiga mengalami kerugian. ${ }^{56}$ Konsep unjust enrichment dikenal baik dalam sistem common law atau Sistem hukum Eropa Kontinental dengan konsep kepatutan. Karena pembayaran oleh pihak ketiga, maka pihak ketiga memiliki hak untuk menggantikan kedudukan kreditur lama. Hak menuntut pemenuhan kewajiban debitur pun beralih kepada pihak ketiga tersebut sebagai kreditur baru. Sedangkan dalam reviving subrogation dimaksudkan untuk menghindari penghapusan kewajiban oleh debitur, karena adanya pembayaran oleh pihak ketiga.

Reviving subrogation merupakan pengalihan hak menuntut pembayaran yang sudah jatuh tempo. Reviving subrogation is therefore the more complicated forms of subrogation, in that it takes rights which have expired and resuscitates them in favour of a party other than the original rightholder. ${ }^{57}$ Reviving subrogation jauh lebih rumit, karena pengalihan melalui subrogasi dilakukan atas kredit dari kreditur yang sudah tidak memiliki kapasitas hukum, karena dilikuidasi atau dinyatakan pailit oleh pengadilan, misalnya, terhadap kredit yang sudah jatuh tempo. Dengan subrogasi, pihak yang membeli kredit dari kreditur lama menghidupkan hak dan berhak menuntut pembayaran dari debitur.

\section{Penutup}

Pengalihan kredit sindikasi merupakan hak kreditur yang selalu diatur dalam perjanjian yang ditujukan sebagai bentuk manajemen risiko dan solusi terhadap masalah likuiditas. Masing-masing metode pengalihan memiliki karakteristik yang berbeda dan membawa implikasi hukum yang berbeda pula. Secara teknis-prosedural, metode (equitable) assignment dan subparticipation bersifat fleksibel. Novasi jauh lebih rumit dilaksanakan dalam kredit sindikasi, karena memerlukan persetujuan dari kreditur-kreditur lain, oleh karena itu, kreditur sindikasi jarang memilih novasi untuk melakukan pengalihan. Namun begitu novasi menjadi basis pengembangan metodemetode pengalihan kredit sindikasi lainnya. Pilihan metode pengalihan kredit sindikasi disesuaikan dengan kepentingan dan kehendak masing-masing kreditur.

${ }^{56}$ Ibid., hal. 3.

${ }^{57}$ Ibid. 


\section{Daftar Pustaka}

Amstrong, Jim. 2003. The Syndicated Loan Market: Developments in the North American Context. Melalui <www.bankofcanada.ca.>

Asser, C. Pengajian Hukum Perdata Belanda. Diterjemahkan oleh Sulaiman Binol, Jakarta: Dian Rakyat, 1991.

Atiyah, P.S. An Introduction to The Contract Law, London: Clarendon Press, 1989.

Corley, Robert N. and William J. Robert. Fundamentals of Business Law, New Jersey: Prentice-Hall Inc. 1974.

Cranston, Ross. Principles of Banking Law, $2^{\text {nd }}$ Edition, London: Oxford University Press, 2002.

Hudson, Alastair. 2003. Equity and Trust. $3^{\text {rd }}$ Edition, Cavendish Publishing Ltd.

Hurn, Stanley. Syndicated Loans, London: Woodhead Faulkner, 1990.

Metzger, Michael B., Jane P. Mallor, A. James Barnes, Thomas Bowers dan Michael J. Phillips. Business Law And The Regulatory Environment: Concepts and Cases, $7^{\text {th }}$ Edition, Irwin Inc., Boston: USA, 1989.

Mitchell, Charles. The Law of Subrogation, London: Clarendon Press, 1994.

Mugasha, Agasha. 2003. The Secondary Market for Syndicated Loans: Loans Trading, Credit Derivatives, and Collateral Debt Obligation. Banking \& Finance Law Review February, Canada: CARSWELL, a Division of Thomson Canada Ltd, 2004.

Norton, Joseph J. International Syndicated Lending and Economic Development in Latin America: The Legal Context. London: The London Institute of International Banking, Finance \& Development Law in cooperation with The International Financial Law Unit, Centre for Commercial Law Studies, Queen Mary \& Westfield College, University of London, and The SMU Institute of International Banking and Finance, 1997.

O'Melveny Gwendoline, Griffiths. 2004. Common Law Issues in Sales of Loan Portfolios. Makalah disampaikan dalam International Bar Association Financial Service Section Conference-Auckland, New Zealand, 28 Oktober 2004, hal. 2. Diakses dari <www.omm.com> pada tanggal 30 September 2005. 
Phang Boon Leong, Andrew. Law of Contract, Singapore: Butterworths, 1994.

Republik Indonesia, Undang-Undang Perbankan

Sjahdeini, Sutan Remy. Kredit Sindikasi: Proses Pembentukan dan Aspek Hukum, Jakarta: Pustaka Utama Grafiti, 1997.

Satrio, J. Cessie, Subrogatie, Novatie, Kompensasi \& Percampuran Hutang, Bandung: Alumni 1999.

Subekti. Pokok-Pokok Hukum Perdata, Jakarta: Intermasa, 1994.

Suharnoko dan Endah Hartati. 2005. Doktrin Subrogasi, Novasi Cessie Dalam Kitab Undang-Undang Hukum Perdata, Niew Nederlands Burgerlijk Wetboek, Code Civil Perancis dan Common Law. Jakarta: Badan Penerbit Fakultas Hukum Universitas Indonesia dan Prenada Media.

Tennekoon, Ravi C. The Law and Regulation of International Finance, London: Butterworths, 1991.

Terry, Brian J. (ed). Corporate Finance, Singapore: Toppan Company Pte., Ltd., 1997. 